Facing Evil 



\title{
FACING EVIL
}

\author{
John Kekes
}

PRINGETON UNIVERSITY PRESS

PRINCETON, NEW JERSEY 
Copyright $\odot 1990$ by Princeton University Press

Published by Princeton University Press, 41 William Street,

Princeton, New Jersey 08540

In the United Kingdom: Princeton University Press, Chichester, West Sussex

All Rights Reserved

Library of Congress-in-Publication Data

Kekes, John.

Facing evil / John Kekes.

Includes bibliographical references.

1. Good and evil. 2 Character. I. Title.

BJ1401.K43 $1991 \quad 170-$ dc20 90-32001

ISBN 0-691-07370-8

ISBN 0-691-02095-7 (pbk.)

This book has been composed in Linotron Baskerville

Princeton University books Press are printed on acid-free paper and meet the guidelines for permanence and durability of the Committee on Production Guidelines for Book Longevity of the Council on Library Resources

Printed in the United States of America

$\begin{array}{lllllllll}10 & 9 & 8 & 7 & 6 & 5 & 4 & 3 & 2\end{array}$ 
For J.Y.K. 
